\title{
ANDRAGOŠKO SPOPOLNJEVANJE IN STROKOVNI RAZVOJ IZOBRAŽEVALCEV ODRASLIH
}

Dr. Tanja Možina

Andragoški center

Slovenije

\section{POVZETEK}

Osrednje vprašanje, s katerim se ukvarjam v prispevku, je, kako lahko z andragoškim spopolnjevanjem podpremo strokovni razvoj izobraževalcev odraslih. To je vse prej kot preprosta in enoznačna naloga. Že v izhodišču nas namreč čaka vprašanje o tem, »kdo je izobraževalec odraslih«, skupaj z zapletenostjo oblikovanja »strokovne identitete izobraževalcev odraslih«. V prvem delu prispevka prikazujem nekatere dosežke, ki kažejo na to, da o izobraževanju odraslih v Sloveniji lahko govorimo kot o stroki (profesiji). V drugem delu predstavljam nekatera izhodišča in cilje prenovljenega koncepta andragoškega spopolnjevanja, ki ga razvijamo na Andragoškem centru Slovenije. Prenovljeni koncept je zasnovan na kompetenčnem pristopu in andragoškem ciklu, pomemben konstitutivni element koncepta pa je tudi vpeljava postopkov priznavanja poprej pridobljenega znanja.

Ključne besede: izobraževalci odraslih, andragogika, profesionalizacija, stroka, andragoško spopolnjevanje, družbena strokovna identiteta, osebna strokovna identiteta, strokovni razvoj izobraževalcev odraslih. .

\section{CONTINUING ANDRAGOGICAL TRAINING AND PROFESSIONAL DEVELOPMENT OF ADULT EDUCATORS - ABSTRACT}

The main issue and the focus of the article is how to support professional development of adult educators with provision of education and training. The task is not simple or easily solved. At the starting point we are faced with the question "who is an adult educator" and with the complexity involved in formation of " the professional identity of adult educators". In the first part of the article I present my research results, which show that in adult education in Slovenia it is possible to speak about a profession. In the second part I present the premises and goals of the renewed concept of training of adult educators, developed by the Slovenian Institute for Adult Education. The renewed concept is based on the competence approach and on the andragogical cycle; one of its important constitutive elements is introduction of the procedures for recognition of prior knowledge.

Keywords: adult educators, andragogy, professionalisation, profession, education and training of adult educators, societal professional identity, personal professional identity, professional development of adult educators

UDK: 374.7

\section{UVOD}

Osrednje vprašanje, s katerim se ukvarjam v prispevku, je, na kakšne načine lahko z andragoškim spopolnjevanjem podpremo strokovni razvoj izobraževalcev odraslih. Strokovni razvoj v tem primeru razumem kot dinamičen vseživljenjski proces učenja, v katerem izobraževalec odraslih pridobiva novo znanje, razvija svojo kompetentnost in profesionalno ravnanje. $\mathrm{V}$ procesu lastnega strokovnega razvoja izobraževalec odraslih:
- pridobiva temeljno in specialistično znanje o izobraževanju odraslih ter to znanje stalno spopolnjuje oz. izgrajuje in razvija svoje zmožnosti za delo z odraslimi,

- s pomočjo refleksije o lastnem delu oblikuje osebne pristope $\mathrm{k}$ učenju in poučevanju in druge oblike dela z odraslimi udeleženci; te se oblikujejo tako na podlagi znanja in teoretičnih načel kot na podlagi refleksije in interpretacije lastne prakse, 
- razvija strokovno identiteto izobraževalca odraslih.

(Mezirow, 2000; Korthagen, 2004; Bron in Jarvis, 2008; Milana in Larson, 2010; Karm, 2007)

Ob sprejetju takšne široke opredelitve strokovnega razvoja smo postavljeni pred strokovni izziv, kako načrtovati programe izobraževanja, usposabljanja in spopolnjevanja, da bomo lahko z njihovo pomočjo spodbujali celovit strokovni razvoj izobraževalcev odraslih. To je vse prej kot preprosta in enoznačno določljiva naloga. Že v izhodišču nas namreč čaka vprašanje o tem, kdo je izobraževalec odraslih, skupaj s kompleksnostjo vprašanja strokovne identitete izobraževalcev odraslih. V nadaljevanju bom najprej razprostrla raznoliko paleto opredelitev »izobraževalcev odraslih« in vlog, ki jih ti opravljajo, kasneje pa se osredinila še na vprašanje strokovne identitete področja izobraževanja odraslih in izobraževalcev odraslih, ki delujejo na tem področju. Ob tem se bom dotaknila tudi vprašanja profesionalizacije izobraževanja odraslih.

\section{KDO SO/SMO IZOBRAŽEVALCI ODRASLIH?}

Izhodišče za premislek o razvoju programske ponudbe za izobraževalce odraslih je opredelitev ciljne skupine oz. ciljnih skupin, za katere bomo tako izobraževanje načrtovali in izpeljevali. Izhajajoč iz raznolikosti in obsežnosti izobraževanja odraslih, lahko izobraževalce odraslih v najširšem smislu opišemo kot veliko skupino strokovnjakov, ki se ukvarja z izobraževanjem odraslih - na različnih ravneh in z različnimi oblikami. To je skupina, ki opravlja številne in raznolike naloge v izobraževanju odraslih - od načrtovanja do izpeljevanja in vrednotenja izobraževanja - ter se ukvarja s številnimi podpornimi in drugimi dejavnostmi, ki spodbujajo odrasle, da se lahko učijo, in jim to omogočajo. V Slovenij, pa tudi drugje, se v izobraževanju odraslih uporablja precej različno strokovno izrazje. V različnih kontekstih različno pojmujejo strokovnjake, ki delajo na tem področju. Skladno z veliko heterogenostjo področja se pojavljajo različne (bolj ali manj uradne) opredelitve in/ali klasifikacije osebja v izobraževanju odraslih, npr.:

- po različnih strokovnih/znanstvenih opredelitvah, navadno opredeljenih tudi v različnih pojmovnikih/terminologijah (npr. andragog/andragoški delavec),

- po strokovni izobrazbi (npr. predmetni učitelj ali profesor v različnih strokah, pedagog, andragog, psiholog idr.),

- po področju dela, ki ga opravljajo (npr. učitelj, mentor, tutor, vodstveno osebje, drugo osebje idr.),

- po obliki zaposlitve (npr. redno zaposleni ali zunanji sodelavci, zaposleni pogodbeno, s polnim delovnim časom),

- po vrsti organizacije, kjer so zaposleni (npr. učitelji, strokovni delavci v osnovni šoli, srednji šoli, na ljudski univerzi, v zasebni izobraževalni organizaciji, knjižnici idr.),

- po opredelitvah v normativnih aktih (npr. v Zakonu o izobraževanju odraslih, v Odredbi o standardih in normativih v izobraževanju odraslih idr.),

- po pojmih, uporabljenih v državni statistiki (strokovni delavec, učitelj, inštruktor, drugo osebje idr.),

- po veljavni standardni klasifikaciji poklicev (andragog/andragoginja, organizator/ organizatorka izobraževanja odraslih).

(Birman Forjanič idr., 2008)

Raznolikost vlog, ki jih opravljajo izobraževalci odraslih, in druge značilnosti, kot so npr. raznolika izobrazba, oblike zaposlitve, raznolikost institucij, v katerih opravljajo delo izobraževalcev odraslih, pokažejo dvoje: (1) da je ugotavljanje potreb po znanjih in snovanje programov izobraževanja, usposabljanja in spopolnjevanja zanje zelo zapletena in zahtevna naloga, (2) da je oblikovanje strokovne identitete izobraževalcev odraslih, ki smo jo opredeli kot pomemben konstitutivni element 
njihovega strokovnega razvoja, zelo težavno. Bron in Jarvis (2008) v prispevku Identitete izobraževalcev odraslih celo ugotavljata, da v izobraževanju odraslih niti ni mogoče govoriti o eni identiteti, temveč gre za razvoj raznolikih identitet posameznih skupin izobraževalcev odraslih.

\section{POTI, PO KATERIH IZOBRAŽEVALCI ODRASLIH VSTOPAJO NA PODROČJE IZOBRAŽEVANIA ODRASLIH}

Ko načrtujemo andragoško spopolnjevanje za izobraževalce odraslih, je zelo pomembno vedeti tudi, s kakšno poprejšnjo izobrazbo in znanji ter predhodnimi izkušnjami slednji prihajajo v programe spopolnjevanja. Prav to področje je eno od tistih, ki so v Sloveniji še slabo raziskana in bi jim bilo treba v prihodnje nameniti več pozornosti.

Praksa kaže, da so osebe, ki se zaposlujejo v izobraževanju odraslih, diplomanti, specializanti ali magistri precej različnih smeri. Učitelji prihajajo v izobraževanje odraslih seveda s svojih temeljnih strokovnih področij. Iz izkušenj in poznavanja področja izobraževanja odraslih lahko sklepamo, da večina strokovnega osebja prihaja z nekaj velikih študijskih področij: iz izobraževanja in družboslovja, poslovnih ved in prava. Izobraževanje odraslih je namreč izrazito interdisciplinarno področje, na katerem (seveda poleg andragogov, pedagogov, organizatorjev izobraževanja in drugih strokovnjakov za izobraževanje odraslih) dela veliko sociologov, psihologov in drugih strokovnjakov s področja družbenih in drugih ved.

Iz nekaterih kvalitativnih tujih in domačih raziskav, ki so temeljile na poglobljenih analizah osebnih biografij izobraževalcev odraslih, lahko izluščimo, da poti, po katerih izobraževalci odraslih vstopajo na to področje, zelo pogosto niso linearne. Iz navedenih študij in raziskav - upoštevajoč prakso izobraževanja odraslih v Sloveniji - lahko povzamemo nekaj vzorcev poti, po katerih izobraževalci odraslih vstopajo v izobraževanje odraslih.

- Prva pot je, da se oseba že v svojem osnovnem dodiplomskem in podiplomskem študiju izobražuje za poklic izobraževalca odraslih, andragoga, oz. da se izobražuje za opravljanje pedagoškega poklica (npr. učitelj) ali drugega družboslovnega poklica, v sklopu tega študija pa si pridobi tudi nekatera andragoška znanja.

- Druga pot, ki je precej pogosta, je, da se oseba v svojem dodiplomskem izobraževanju ni izobraževala za opravljanje vloge izobraževalca odraslih oz. tudi ni pridobivala pedagoške ali andragoške izobrazbe, temveč si ta znanja pridobiva kasneje, bodisi $\mathrm{v}$ formalnem izobraževanju (v Sloveniji npr. $\mathrm{z}$ vključitvijo v programe za pridobitev pedagoško-andragoške izobrazbe) bodisi $\mathrm{v}$ programih andragoškega usposabljanja in spopolnjevanja.

(Milana in Larson, 2010; Karm, 2007; ALPINE, 2008; Možina in Birman Forjanič, 2009)

Prav tako kot izobrazba, s katero osebe, ki delujejo v izobraževanju odraslih, vstopajo na to področje, so pomembni tudi motivi, ki so jih vodili, da so se odločile za to delo. Posebno pozornost je treba nameniti kazalnikom, ki kažejo, da v številnih primerih vstop na področje izobraževanja odraslih ni bila namerna

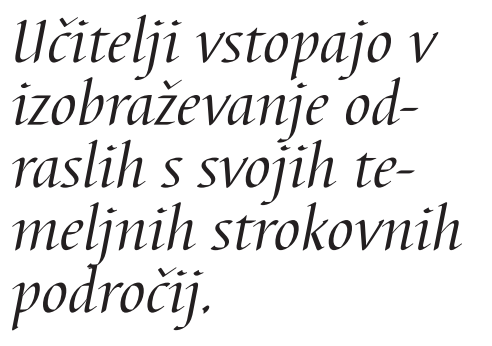
odločitev posameznika, temveč se je ta vstop zgodil bolj »po naključju« oz. zaradi različnih zunanjih vplivov, kot so: pomanjkanje delovnih mest $\mathrm{v}$ osnovnem poklicu - dejavnost izobraževanja odraslih je delček dejavnosti v poklicu, ki ni poklic s področja izobraževanja odraslih (npr. kmetijski pospeševalci, medicinske sestre, knjižničarji, kustosi v muzejih ipd.). Ob tem se namreč zastavlja vprašanje razvoja poklicne oz. strokovne identitete izobraževalca odraslih, še posebno v primerih, ko ta npr. pomeni nadgradnjo identitete, ki si jo je 
oseba pridobila v svojem temeljnem poklicu, ki ni (bil) poklic izobraževalca odraslih.

\section{POKLICNA IN STROKOVNA IDENTITETA IZOBRAŽEVALCA ODRASLIH KOT KONSTITUTIVNI ELEMENT NJEGOVEGA STRO- KOVNEGA RAZVOJA}

Ob odpiranju vprašanja poklicne identitete izobraževalca odraslih takoj trčimo na terminološko težavo, ki pa ima globljo vsebinsko podlago. V slovenskem prostoru se angleški izraz »professional (occupational) identity « navadno prevaja v slovenski izraz »poklicna identiteta«. Muršak (2002: 81) v pojmovnem slovarju za področje poklicnega in strokovnega izobraževanja ob opredelitvi pojma »poklicna identiteta« zapiše, da se »poklicna identiteta oblikuje $v$ procesu poklicne socializacije in predstavlja posameznikovo doživljanje sebe $v$ povezavi s poklicem, poklicnim delom, ki ga opravlja. Je socialno priznan način, na katerega se posamezniki poistovetijo drug $z$ drugim na področju dela, poklicnem področju ali področju zaposlitve.« Razvoj poklicne identitete se začne že v času izobraževanja, priprave na poklic, čeprav je njen resnični razvoj povezan z opravljanjem poklicnega dela in je najbolj odvisen od referenčne skupine, v kateri deluje posameznik pri svojem poklicnem delu (Muršak, 2002).

Razvoj poklicne identitete se torej povezuje s »poklicem«ali »poklicnim področjem, poklicnim delom «, ki ga posameznik opravlja. In tu je že prva zagata. V našem prispevku že ves čas govorimo o »izobraževalcu odraslih «, vendar ali je »izobraževalec odraslih « poklic? ${ }^{1}$

Prikaz poti, po katerih izobraževalci odraslih vstopajo na to področje, je razkril, da se v skupini oseb, ki jih poimenujemo »izobraževalci odraslih«, znajdejo tako tisti, ki so to zares po poklicu, ${ }^{2}$ npr. andragogi, kot tisti, ki so po svojem temeljnem poklicu nekaj drugega, npr. učitelji, sociologi, psihologi, ekonomisti, agronomi idr. Njihova identiteta izobraževalca odraslih se v tem primeru ne povezuje $\mathrm{z}$ njihovim temeljnim poklicem, temveč pomeni nadgradnjo njihove temeljne poklicne identitete.

Odpre se nam vprašanje o razmerju oz. razliki med poklicem v ožjem in širšem pomenu ter o razmerju med poklicem in stroko. Gre za vprašanja, ki so v izobraževanju odraslih morda še bolj kot na drugih področjih vedno znova aktualna, hkrati pa tudi kompleksna in v nekaterih vidikih kontradiktorna, še posebej zaradi velike raznolikosti področja ter vlog izobraževalcev odraslih. Na pomen teh vprašanj opozarja tudi Z. Jelenc (2010) v prispevku Usposabljanje in identiteta izobraževalcev odraslih, ko pravi, da imamo pri izobraževanju odraslih, izhajajoč iz velike raznolikosti in nekoherentnosti sistema, identitetne težave $\mathrm{z}$ dveh zornih kotov:

- z zornega kota izobraževanja odraslih kot stroke in

- z zornega kota družbene identitete stroke, ki jo štejemo za izobraževanje odraslih.

Na teh dveh namreč temelji še tretja identiteta, to je:

- osebna identiteta izobraževalca odraslih s stroko in dejavnostjo izobraževanja in učenja odraslih (Jelenc, 2010).

Zaradi posebnosti izobraževanja odraslih bom $\mathrm{v}$ nadaljevanju namesto pojma $\gg$ poklicna identiteta « uporabljala pojem »strokovna identiteta«, sodim namreč, da s tem pojmom ustrezno zajamemo tako identifikacijo s poklicem na področju izobraževanja odraslih kot identifikacijo $s$ strokovnim področjem izobraževanja odraslih, tudi v primerih, ko oseba dejavnosti izobraževanja odraslih ne opravlja poklicno.

Za nadaljnji razmisek pa se nam odpira vprašanje, kako poskrbeti za strokovno usposobljenost tistih izobraževalcev, ki to delo opravljajo kot del svojega poklica in zaposlitve; še večji izziv za načrtovalce strokovnega spopolnjevanja pa je velika skupina, v katero sodijo izobraževalci odraslih, ki tega dela ne opravljajo poklicno niti niso zaposleni na delovnih me- 
stih s področja izobraževanja odraslih, vendar del njihovega dela zajema tudi delo z odraslimi. Vemo namreč, da sodi velik del izobraževalcev odraslih prav v to skupino.

\section{IZOBRAŽEVANJE ODRASLIH KOT STROKA}

Ustavimo se najprej ob vprašanju izobraževanja odraslih kot stroke. Tudi tu naletimo pri prevajanju angleškega strokovnega izrazja v slovenski jezik na kar nekaj težav, ki se pokažejo $\mathrm{v}$ razmerju med pojmoma poklic in stroka. Muršak (2002) opozarja na pojem poklica v pomenu »profesije« (iz angleškega pojma »profesion «), torej akademski poklic kot naziv diplome, npr. zdravnik, pravnik idr. Pri obravnavi koncepta »profesije « v literaturi zasledimo t. i. trši in mehkejši pristop, to pa pokaže na potrebo po širši obravnavi tematike. Ko govorimo o profesionalizaciji izobraževanja odraslih v Sloveniji, namreč ni dovolj, če s tem mislimo zgolj del profesionalizacije, ki zadostuje kriterijem, ki jih opredeljuje t. i. trši pristop, temveč je treba pozornost nameniti tudi tistemu delu procesa profesionalizacije, ki jih obravnavajo t. i. mehkejši pristopi. Oba vidika bomo v nadaljevanju osvetlili v širšem kontekstu izobraževanja odraslih kot stroke. Skladno s »tršim « pristopom mora neka dejavnost, da postane stroka, izpolnjevati nekatere stroge kriterije, kot so:

- raziskovalno in teoretsko utemeljen korpus znanja (področje vednosti), ki določa (ideološko) teoretsko zasnovo vede,

- formalni sistem izobraževanja, ki določa minimalne zahteve za to, da si posameznik pridobi pravico do opravljanja te dejavnosti, in ki zagotavlja minimalno kvaliteto,

- nadzor s pomočjo certificiranja, ki ga običajno opravlja šolski sistem in ki ima hkrati tudi močno selekcijsko in kontrolno funkcijo,

- formalno organizirana socialna skupina, ki opravlja funkcije določanja poklicnega statusa in ščitenja poklicnih interesov, recimo v obliki strokovnih in poklicnih sindikalnih združenj, ki imajo različno moč in vlogo, pač odvisno od stopnje organiziranosti in družbene organizacije, to pa povratno vpliva tudi na pomen in vlogo certificiranja in priznavanja poklicnega statusa,

- vzpostavitev in izvajanje kodeksa ravnanja,

- ustaljen sistem razvoja poklicne kariere, ki vključuje določanje plač in plačnih razredov, karierno napredovanje ter bolj ali manj ustaljen sistem nadgradnje in razvoja poklicnih kompetenc,

- strokovna avtonomija, ki izhaja iz družbenega priznavanja te stroke.

(Tobias, 1996)

V tem smislu se profesionalizacija izobraževanja odraslih utemeljuje $\mathrm{z}$ raziskovalno/teoretsko zasnovanim korpusom znanja, obvezno pa vključuje tudi možnost začetnega in nadaljnjega izobraževanja izobraževalcev odraslih, ki vodi v certificiranje tega znanja.

Profesionalizacija izobraževanja odraslih v svojem »mehkejšem « pogledu pa je odvisna od razvoja skupnega občutka identitete med ljudmi, ki so angažirani v podobnih dejavnostih in imajo skupen občutek namena, smisla oz. poslanstva. Navadno zahteva vzpostavitev nekega organizacijskega okvira, ki omogoča, da se ta občutek skupnega namena lahko izrazi. To vključuje tudi razvoj raznolikih programov izobraževanja in usposabljanja, ki pa pogosto niso povezani s pridobivanjem certifikatov (s certificiranjem znanja).

Če na področju izobraževanja odraslih izhajamo iz »trše različice« koncepta stroke in ožje opredelitve pojma poklic »kot statistično-analitične enote, v katero se razvrščajo dela, ki so podobna po vsebini in zahtevnosti «, in v zvezi s tem upoštevamo stalno klasifikacijo poklicev, ki jo poznamo v Sloveniji, ugotovimo, da ta za področje izobraževanja odraslih ni razdelana. Vsebuje namreč le osnovna poklica andragog in organizator izobraževanja odraslih. Iz prakse pa vemo, da je v izobraževanju odraslih še cela vrsta drugih opravil/delovnih mest, 
ki niso sistematično opisana. Andragoško delo je namreč zelo segmentirano, odvisno od tega, kje poteka, kakšni so njegova vsebina in cilji. Področje se tudi zelo hitro razvija, tako rekoč čez noč nastajajo nove oblike in možnosti andragoškega dela.

To veliko raznolikost delovnih vlog na področju izobraževanja odraslih povzema tudi Terminologija izobraževanja odraslih iz leta 1991. Ta vpeljuje dva pojma, in sicer »andragog « in »andragoški delavec«. »Andragog je strokovnjak $z$ visoko strokovno izobrazbo, ki je usposobljen za andragogiko in izobraževanje odraslih, ali pa z visoko izobrazbo kake druge smeri in javno priznano specializacijo $i z$ andragogike ali izobraževanja odraslih.« (Jelenc, 1991: 23.) »Andragoški delavec je strokovnjak, ki dela v izobraževanju odraslih, vendar za to delo nima javno priznane stopnje izobrazbe ali specializacije iz andragogike. Tudi delavec v izobraževanju odraslih, izobraževalec odraslih.«(Prav tam, str. 23.)

$\mathrm{V}$ nadaljevanju premislimo, kateri so danes tisti elementi na področju izobraževanja odraslih, ki - skladno s »tršo « različico koncepta stroke - kažejo na to, da v Sloveniji lahko govorimo o profesionalizaciji tega področja ali o izobraževanju odraslih kot o stroki. Gre za pomemben premislek, saj je močno povezan $\mathrm{z}$ vprašanjem razvoja družbene identitete področja izobraževanja odraslih in izobraževalcev odraslih.

Ana Krajnc (2011) v prispevku Študij andragogike in izobraževanje andragogov opisuje pomemben del razvoja izobraževanja odraslih, ki je - izhajajoč iz bogate tradicije izobraževanja odraslih v Sloveniji v preteklih obdobjih, v drugi polovici prejšnjega stoletja, še posebno pa po letu 1991, ko je Slovenija postala samostojna država - postopoma šel v smeri profesionalizacije.

Od prikazanega velja za namene našega prispevka posebej omeniti naslednje:

- razmah prakse izobraževanja odraslih v raznih oblikah (večerne šole, kulturna dru- štva, usposabljanje delavcev $\mathrm{v}$ tovarnah), ustanavljanje delavskih in ljudskih univerz, razvoj skupin s področja izobraževanja odraslih;

- krepitev raziskovalnega dela kot prvega pogoja za razvoj teorije izobraževanja odraslih, ki se je gradilo ob upoštevanju konteksta slovenskega prostora izobraževanja odraslih in značilnosti tega področja; ob tem je bilo raziskovalno delo ves čas močno povezano $\mathrm{z}$ opazovanjem andragoške prakse in sodelovanjem $\mathrm{z}$ andragoškimi ustanovami;

- ustanovitev Andragoškega društva Slovenije kot osrednjega stanovskega društva, ki povezuje izobraževalce odraslih;

- ustanovitev Andragoškega centra Slovenije kot osrednje raziskovalne in razvojne institucije za področje izobraževanja odraslih v Sloveniji;

- razvoj strokovne terminologije in izdajanje terminoloških slovarjev (Terminologija s področja izobraževanja odraslih, 1991; Terminologija s področja poklicnega in strokovnega izobraževanja, 2002 - slednja ni oblikovana posebej za področje izobraževanja odraslih, vendar jo izobraževalci odraslih veliko uporabljamo, saj zajema velik del izobraževanja odraslih ter poklicno in strokovno izobraževanje);

- oblikovanje študijskega programa za andragogiko na Univerzi v Ljubljani;

- razvoj programa za pridobitev pedagoško-andragoške izobrazbe;

- razvoj andragogike na drugih slovenskih univerzah (še posebej programi za pridobitev pedagoško-andragoške izobrazbe);

- razvoj strokovne literature in prve slovenske revije za izobraževanje odraslih Andragoška spoznanja.

(Krajnc, 2011)

$\mathrm{Z}$ vidika razvoja izobraževanja odraslih kot stroke, še posebej njegove sistemske ureditve, lahko temu dodamo še vsaj ustanovitev strokovnega sveta za izobraževanje odraslih in 
sektorja za izobraževanje odraslih pri ministrstvu za šolstvo in šport ter sprejetje Zakona o izobraževanju odraslih.

Gotovo nismo izčrpali vseh pomembnih elementov, ki so v preteklih obdobjih pomembno pripomogli $\mathrm{k}$ razvoju in profesionalizaciji izobraževanja odraslih. Za te, ki smo jih navedli, pa vendarle velja reči, da gre za zelo velike korake, ki so pomembna sidrišča tako za krepitev družbene kot osebne strokovne identitete izobraževalcev odraslih. In če ne drugega, bi bilo treba vsaj tu pa tam tudi v strokovnih andragoških krogih izreči priznanje in izkazati spoštovanje vsem tistim strokovnjakom, ki so prispevali svoj delež k doseganju teh pomembnih razvojnih mejnikov.

Seveda pa se moramo izobraževalci odraslih na zgornje dosežke zazreti tudi iz današnjega trenutka in $v$ današnjem kontekstu ter se vprašati, kaj se danes dogaja $\mathrm{z}$ vsemi temi pomembnimi elementi profesionalizacije andragoškega dela in kako jih nadgrajevati $\mathrm{v}$ prihodnje. S tega zornega kota so pomembna opozorila, ki jih v prispevku Paleta izbire na področju izobraževanja odraslih - resničnost in obeti, ob kritični analizi sedanjega stanja, navaja S. Jelenc Krašovec (2011). Ob ugotovitvi, da je bila po osamosvojitvi Slovenija zares neverjetna v svojem razvoju na področju izobraževanja odraslih, saj se je ob ustrezni politični podpori, močni civilni družbi ter kritičnih in ustvarjalnih državljanih zares hitro razvijala in že skoraj lahko stopila ob bok k stalnemu učenju naravnani skandinavski druščini socialnih držav, zapiše tudi, da se danes s tem ne moremo več pohvaliti.

Za našo razpravo o profesionalizaciji področja izobraževanja odraslih in nadaljnjem razvoju andragoškega spopolnjevanja je pomembno njeno opozorilo, da se danes »andragogika kot akademska disciplina ne razvija povsem tako, kot bi si želeli; delno je za to krivo pomanjkanje ustrezno usposobljenih raziskovalcev, $k i$ bi lahko izvajali raziskave tako na nacionalni kot mednarodni ravni, delno pa je to tudi posledica neustrezne podpore ministrstev« (Jelenc Krašovec, 2011: 8). Opozarja še na »marginaliziranost nadaljevalnega izobraževanja, ki se kaže tudi v prepogosto neustrezno izobraženih učiteljih in drugih strokovnjakih, ki delajo na področju izobraževanja odraslih; to so nemalokrat učitelji, ki v dopoldanskem času poučujejo mladino, nimajo izkušenj z izobraževanjem odraslih in imajo tudi (pre)malo teoretskega znanja« (prav tam, str. 9).

Krajnčeva (2011) tako kot številni drugi strokovnjaki s področja izobraževanja odraslih podobno razmišljanje izrazi tudi o raziskovalni vlogi Andragoškega centra Slovenije, ko zapiše: »Danes Andragoški center žal nima več raziskovalne funkcije, čeprav si težko predstavljamo, koliko časa in kako kakovostno bo razvojno delo, če ne bodo sproti raziskovali dejanske stvarnosti $v$ andragoški praksi. (Prav tam, str. 18.) Temu lahko dodamo še, da je danes čedalje teže zagotavljati sredstva za izdajanje revije Andragoška spoznanja, da izobraževalci odraslih pogosto izražajo nezadovoljsto s premajhno močjo, ki jo imata v sistemu izobraževanja odraslih strokovni svet za izobraževanje odraslih in sektor za izobraževanje odraslih pri ministrstvu za šolstvo in šport. Andragoško društvo Slovenije pogosto opozarja na sistemske pomanjkljivosti, vendar je vprašanje, koliko mu danes uspeva povezovati strokovnjake s področja izobraževanja odraslih. Občutek je, da se razvoj področja izobraževanja odraslih v zdajšnjem obdobju ne nadaljuje $\mathrm{s}$ takšno intenzivnostjo, kot je bilo to značilno npr. za obdobje po osamosvojitvi in že pred njo. S tem pa izobraževalci odraslih izgubljamo pomembna sidrišča, na katera bi lahko vezali tako razvoj družbene kot osebne strokovne identitete področja izobraževanja odraslih in vloge izobraževalca odraslih.

$\mathrm{Na}$ trenutke se tako zdi, da je nekakšno malodušje in nezadovoljstvo, ki je v zadnjem obdo- 
bju zajelo mlado državo Slovenijo, zajelo tudi mlado vedo andragogiko. Vendarle bo prav, da se navkljub vsem težavam, s katerimi se ubada stroka izobraževanja odraslih, izobraževalci odraslih ne pustimo popolnoma ujeti $\mathrm{v}$ to trenutno družbeno klimo. Vloga izobraževalcev odraslih je bila namreč v zgodovini ravno nasprotna. Vključevala je iskanje odgovorov na družbene izzive, hkrati pa tudi iskanje odgovorov na izzive lastne stroke. In ob tem ne gre pozabiti, da je pomembno jedro razvoja stroke tudi samoizpraševanje njenih nosilcev o lastnem prispevku k temu razvoju. Na prej opisano stanje lahko namreč pogledamo tudi drugače.

Čeprav smo npr. pri študiju andragogike v nekem obdobju imeli samostojen naziv dipl. andragog, pa ga danes v takšni obliki nimamo več, velja vendarle poudariti, da študij andragogike tudi danes še imamo, in strokovnjaki, ki se bojujejo za obstanek te vede na univerzi, bi verjetno vedeli povedati marsikaj o tem, kako težko je tej mladi vedi vedno znova ohranjati prostor, pa vendarle jim to uspeva. Z novimi bolonjskimi študijskimi programi smo poleg prvostopenjskega enotnega študijskega programa pedagogika in andragogika, ki daje naziv profesor/profesorica pedagogike in andragogike, dobili drugostopenjski študijski program andragogika, strokovni naziv, ki ga pridobi diplomant, pa je magister profesor andragogike oz. magistrica profesorica andragogike, ter tretjestopenjski študijski program andragogika, strokovni naziv pa je doktor znanosti oz. doktorica znanosti.

Med pozitivnimi vidiki ne gre zanemariti tudi vloge združenj s področja izobraževanja odraslih, ki so v zadnjem obdobju zelo dejavna in povezujejo strokovnjake, ki delujejo $\mathrm{v}$ istovrstnih oblikah izobraževanja. S svojim delovanjem ta združenja ne pripomorejo le $\mathrm{k}$ udejanjanju svojih interesov, temveč s tem, ko izboraževalcem odraslih omogočajo povezovanje s tistimi, s katerimi jih družijo podobni interesi, cilji in prakse izobraževanja odraslih, spodbujajo tudi razvoj družbene identitete izobraževalcev odraslih. V zadnjem obdobju pa so ta združenja precej dejavna tudi pri zagotavljanju spopolnjevanja svojih članov glede uvajanja novosti v izobraževanje odraslih, organiziranja študijskih obiskov v tujini ipd.

Izobraževalci odraslih nismo vedno zadovoljni z delovanjem sektorja za izobraževanje odraslih pri ministrstvu za šolstvo in šport, predvsem ne s prešibko vlogo, ki jo ima $\mathrm{v}$ sistemu. Predstavniki sektorja za izobraževanje odraslih pa bi verjetno vedeli povedati marsikaj o tem, kako težko je vsakič znova izbojevati sredstva za izobraževanje odraslih ob številnih interesih, ki prihajajo $\mathrm{z}$ drugih področij izobraževanja. Pa vendarle velja med pozitivnimi vidiki poudariti, da je na področje izobraževanja odraslih iz Evropskega socialnega sklada prišlo kar nekaj sredstev, ki so nam v zadnjih letih, ob precejšnji krnitvi sredstev iz domačega proračuna, vendarle omogočila, da smo lahko vsaj v omejenem obsegu udejanjali razvoj izobraževanja odraslih. In s teh pozitivnih izhodišč, upoštevajoč vse omenjene pasti, je verjetno treba graditi delo naprej.

In enako velja za Andragoški center Slovenije. Res je, da je zaradi različnih razlogov (tako zunanjih kot notranjih) v zadnjih letih doživel večje pretrese, kar je zares tudi ošibilo njegovo raziskovalno, pa tudi druge vloge. Sodelavci Andragoškega centra bi lahko veliko povedali o tem, kaj vse se je v zadnjih letih nagrmadilo na naše delovne mize ter vzelo prostor poglobljenemu raziskovalnemu in razvojnemu delu, a si vendarle marsikdo od nas celotne delovne mize ni pustil odvzeti! In resnici na ljubo je treba povedati, da je marikatera študija in razsikava na specialističnih področjih izobraževanja odraslih v zadnjih letih prišla tudi izpod peresa strokovnjakov Andragoškega centra.

Zato si upam trditi, da tudi danes na področju izobraževanja odraslih Andragoški center opravlja pomembno vlogo, še posebej, ko gre za razvojno delo ter spodbujanje procesov strokovnega razvoja izobraževalcev odraslih 
in njihove strokovne identifikacije s tem področjem. Na Andragoškem centru ima ves čas pomembno vlogo prav dejavnost andragoškega spopolnjevanja. $\mathrm{V}$ to dejavnost se namreč vključujejo tako tisti izobraževalci odraslih, ki so po svojem temeljnem poklicu andragogi ali so si pedagoško-andragoško izobrazbo pridobili po drugih poteh, kakor tudi številni tisti, ki niso šli po tej poti.

Na tej točki premislimo še o procesu razvoja izobraževanja odraslih in strokovnega razvoja izobraževalcev odraslih z »mehkejšega« vidika koncepta stroke ter razvoja profesionalizma pri izobraževanju odraslih. Profesionalizem $\mathrm{v}$ tem pomenu je kompleksen, počasi nastajajoč, nelienaren kontinuum, ki je zgodovinsko, družbeno in kulturno pogojen. Posledično lahko proces profesionalizacije razumemo kot stalno rast in razvoj kvalitet, potrebnih za profesionalno ravnanje $\mathrm{v}$ nekem družbenem kontekstu. Ob tem je nujno, da si izobraževalci odraslih pridobivajo specializirano znanje o izobraževanju odraslih in to stalno nadgrajujejo. $\mathrm{Ni}$ pa nujno in potrebno, da tako pridobivanje znanja vedno vodi v njegovo certificiranje.

Mcintosh (2008) v prispevku Profesionalizacija izobraževalcev odraslih v kanadski učeči se družbi (Professionalization of adult educators in a Canadian Learning Society) v zvezi s tem opozarja na nevarnost, da bi prevelika profesionalizacija, ki temelji na standardiziranju znanja in ostrih vstopnih pogojih za osebje, ki deluje v izobraževanju odraslih, lahko ogrozila prav najbolj imanentno jedro dejavnosti izobraževanja odraslih, ki v svojem zelo obsežnem delu zajema neformalno izobraževanje, ki samo po sebi ne prenese prevelike standardizacije. Gre za delo, ki ga zelo pogosto opravljajo prostovoljci kot amaterji. Na teh načelih je $\mathrm{v}$ številnih državah po svetu zgrajeno močno izobraževanje odraslih $\mathrm{v}$ lokalni skupnosti. Mcintosh se tako zavzema za to, da se ob vprašanju razvoja izobraževanja odraslih kot stroke upošteva omenjena raznolikost izobraževanja odraslih.
Pomembno pa je, da izobraževalcem odraslih zagotovimo dovolj močan in verodostojen organizacijski okvir, ki jim bo poleg pridobivanja kakovostnega znanja in zmožnosti za izobraževanje odraslih omogočal tudi druženje, izmenjavo izkušenj in praks ter strokovno razpravo z drugimi izobraževalci odraslih. To je nujni pogoj za izgradnjo osebne strokovne identitete izobraževalca odraslih, če izhajamo iz tega, da se ta lahko razvija le v odnosu med posameznikom in njegovim družbenim okoljem, v tem primeru strokovnim/profesionalnim družbenim okoljem.

Vključitev v programe andragoškega spopolnjevanja in srečevanje s kolegi, ki delujejo $\mathrm{v}$ izobraževanju odraslih, je zato $\mathrm{z}$ zornega kota njihovega strokovnega razvoja tudi za slovenski prostor izobraževanja odraslih zelo pomembno, Andragoški center Slovenije pa je pri tem eno izmed pomembnih mest, kjer jim je to lahko omogočeno. To je hkrati skladno s temeljnim poslanstvom delovanja centra, ki je bilo začrtano ob njegovi ustanovitvi. To poslanstvo se zrcali že v samem imenu institucije, ki naj bi opravljala vlogo »andragoškega centra Slovenije «, centra, ki goji andragoško vedo in jo tudi s pomočjo andragoškega spopolnjevanja razširja med izvajalce izobraževanja odraslih. Hkrati pa tudi takšnega »andragoškega centra«, kjer se lahko srečujejo izobraževalci odraslih iz vse Slovenije, izmenjujejo svoje znanje in izkušnje ter se nato vračajo $\mathrm{v}$ svoja lokalna okolja, kjer s svojim znanjem ta okolja bogatijo in prispevajo $\mathrm{k}$ njihovi rasti.

Le redki izobraževalci odraslih, tudi zaposleni na Andragoškem centru, se danes tu pa tam še zares zazrejo v logotip (znak ACS), ki nosi prav to sporočilo. Pot, ki izobraževalce odraslih vodi v središče - Andragoški center Slovenije - ter obogatene spet ven, v lokalna okolja.

Ko smo v zadnjih letih na Andragoškem centru opravili temeljit premislek o nadaljnjem razvoju andragoškega spopolnjevanja in oblikovali tudi novo celostno podobo tega spo-

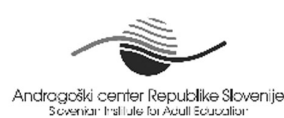

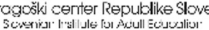

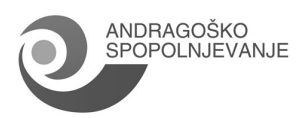


polnjevanja, smo poskušali v novi logotip, ki označuje dejavnost andragoškega spopolnjevanja, vključiti prav to sporočilo, saj simbolno kaže izhodišča, na katerih želimo to dejavnost razvijati v prihodnje, in je hkrati imanentni del temeljnega poslanstva in identitete Andragoškega centra Slovenije. Logotip ponazarja pot (svetlo modra zgornja vijuga), po kateri izobraževalci odraslih prihajajo na andragoška usposabljanja in spopolnjevanja na Andragoški center (zelena pika), ter pot (temno modra vijuga), po kateri odhajajo naprej, v svoja delovna okolja, obogateni z novih znanjem, izkušnjami, novimi poznanstvi, ki so jih stkali ob tovrstnih druženjih, in utrjenimi povezavami s svojimi kolegi, drugimi izobraževalci odraslih.

Iz tega premisleka o procesu profesionalizacije področja izobraževanja odraslih lahko povzamemo:

- da je treba z namenom utrjevanja andragogike kot stroke še naprej razvijati koncept »stroke« v t. i. tršem pomenu, kar pomeni nadaljnji razvoj teoretskega znanja na tem področju, skrb za formalno, predvsem tudi akademsko izobraževanje izobraževalcev odraslih, ki v tem delu vodi v certificiranje oz. javno potrjevanje znanja. Krepiti je treba strokovna združenja, ki jih sestavljajo kompetentni strokovnjaki s področja izobraževanja odraslih. Temu je treba dodati krepitev sistemskih elementov, kot so: razvoj strategije izobraževanja odraslih, nadaljnje umeščanje izobraževanja odraslih kot enakovrednega dela sistema vzgoje in izobraževanja, ustreznejša zakonska ureditev in upravljanje izobraževanja odraslih. Ta del profesionalizacije izobraževanja odraslih je nujen, če želimo krepiti družbeno strokovno identiteto področja izobraževanja odraslih, kar prinaša tudi večjo strokovno avtonomijo. Ob tem v prihodnosti velja premisliti, ali bi bilo smiselno in potrebno, da bi poleg delovnega mesta andragoga in organizatorja izobraževanja v proces »strožje « profesionalizacije vključili tudi nekatere druge vloge in delovna mesta s področja izobraževanja odraslih, kot so svetovalec v svetovalnih središčih ISIO, učitelj v programih Usposabljanja za življenjsko uspešnost (UŽU), mentor v programu Projektno učenje za mlajše odrasle (PUM). Premislek gre tu lahko vsaj v dve smeri: ali v izpeljavo postopkov, da se ta delovna mesta vključijo v standardno klasifikacijo poklicev, ali pa, da se strožji kriteriji profesionalizacije zagotovijo s ponovno uvedbo instrumenta (obnovljivih) licenc za opravljanje neke vloge (kot sta npr. učitelj UŽU, mentor PUM), kar smo pred časom v sistemu že poznali.

- Hkrati s tem pa je treba skrbeti za profesionalizacijo izobraževanja odraslih tudi s t. i. mehkejšim pristopom. Če želimo ohraniti pomemben del neformalnega izobraževanja, ne bi bilo smiselno, da bi ga poskušali na silo spravljati v okvire prevelike profesionalizacije, še posebej standardizacije in normativizacije. Prav tako ni smiselno za vsako ceno standardizirati in profesionalizirati vseh vrst dela in vlog, ki jih opravljajo izobraževalci odraslih. Slogan »Znaš, povej naprej«, ki smo ga lahko v zadnjem obdobju zasledili na promocijskih plakatih Univerze za tretje življenjsko obdobje, na zelo preprost in učinkovit način pove, kako deluje velik del izobraževanja odraslih. Znanja, ki si ga med seboj na neformalen način prenašajo člani lokalne skupnosti, nekega društva ipd., ni smiselno zavirati s premočnim uokvirjanjem. Hkrati s tem pa je pomembno zagotoviti, da je osebje, ki se $\mathrm{v}$ teh vlogah vključuje $\mathrm{v}$ izobraževanje odraslih, še posebno takrat, ko ima to izobraževanje pomen javnega delovanja, usposobljeno za to delo. Tako tisti izobraževalci odraslih, ki jih lahko razvrstimo v »trši « del profesionalizacije izobraževanja odraslih, kot tisti del, ki je pomemben $\mathrm{z}$ vidika profesionalizacije izobraževanja odraslih $\mathrm{v}$ 
t. i. mehkejšem smislu, pa potrebuje prostor za srečevanje, izmenjavo lastnih praks in krepitev občutka pripadnosti skupnosti izobraževalcev odraslih. V ta del krepitve procesa profesionalizacije po našem mnenju lahko najbolje uvrstimo dejavnost andragoškega spopolnjevanja, ki jo izvajamo na Andragoškem centru Slovenije.

$\mathrm{V}$ nadaljevanju se bom zato osredotočila na predstavitev nekaterih konceptualnih izhodišč, na katerih smo, izhajajoč iz poglobljene refleksije, ki smo jo opravili v zadnjih letih, zastavili nadaljnji razvoj te dejavnosti.

\section{OPREDELITEV IZHODIŠČ AN- DRAGOŠKEGA SPOPOLNJEVA- NIA NA ANDRAGOŠKEM CEN- TRU SLOVENIJE}

\section{Opredelitev pojma »andragoško spopolnjevanje«}

Razjasnimo najprej terminološka izhodišča. Zakaj smo se odločili za poimenovanje »andragoško spopolnjevanje«? Najprej zato, da smo to izobraževanje izobraževalcev odraslih razmejili od temeljnega (začetnega ali nadaljevalnega) formalnega dodiplomskega in podiplomskega andragoškega in drugega »izobraževanja « ter formalnega pridobivanja pedagoško-andragoške izobrazbe po obstoječih javnoveljavnih programih. »Spopolnjevanje« pomeni »nadaljnje« izobraževanje in je kontinuiteta temeljnemu.

$\mathrm{V}$ nasprotju s formalnim dodiplomskim izobraževanjem gre pri programih andragoškega spopolnjevanja, ki jih razvijamo in izvajamo na Andragoškem centru Slovenije, večinoma za spopolnjevanje izobrazbe, ki jo je posameznik pridobil bodisi s formalnim dodiplomskim izobraževanjem bodisi z izobraževanjem na svoji nadaljnji poklicni poti, to je z nadaljnjim izobraževanjem. Praviloma je to izobraževanje neformalno, lahko pa bi v nekaterih primerih pridobilo tudi status formalnega, za kar si je Andragoški center Slovenje prizadeval ves čas svojega delovanja. Če bo v prihodnosti več posluha za pobude in predloge Andragoškega centra, bi se pridobljena znanja $\mathrm{v}$ nekaterih primerih formalizirala, najverjetneje $z$ uvedbo licenc, ki si jih mora pridobiti izobraževalec odraslih za opravljanje neke specializirane vloge (npr. mentor PUM, učitelj UŽU, svetovalec v svetovalnem središču ISIO, svetovalec za kakovost, vodja in mentor središča za samostojno učenje idr.).

Gre za programe, ki jih Muršak (2002: 49) pri opredelitvi pojma »izpopolnjevanje« opredeli kot "programe, namenjene poglabljanju in širitvi poklicnega znanja«. Podobno, četudi nekoliko širše, pojasnjujejo izraz v Terminologiji izobraževanja odraslih, kjer strokovno izpopolnjevanje opredeljujejo kot »izobraževanje, namenjeno strokovnjakom $v$ praksi, ki opravljajo zelo zahtevna poklicna dela, da bi lahko sledili razvoju na svojem področju, si pridobivali nove spretnosti, ki jih zahteva delovno mesto, in razumeli družbene okoliščine, v katerih delujejo "(Jelenc, 1991: 63).

Ob tem velja omeniti še, da se je za izobraževalno dejavnost, ki jo izvajamo in razvijamo na Andragoškem centru Slovenije, v zadnjih letih uporabljal izraz »usposabljanje«. Ta izraz se je udomačil, čeprav je s stališča razvoja izobraževalne dejavnosti in širše strokovne rabe preozek (Birman Forjanič idr., 2008). Z izrazom »usposabljanje« Muršak (2002: 149) označuje predvsem urjenje ali pridobivanje praktičnih spretnosti, ki »praviloma ni povezano z zahtevnejšimi intelektualnimi operacijami ali strokovno teorijo «. Izhajajoč $\mathrm{z}$ nekoliko drugačne predpostavke, namreč, da se lahko usposabljamo na različnih ravneh zahtevnosti, je izraz nekoliko širše pojasnjen v Terminologiji izobraževanja odraslih: »Postopen razvoj nekega ravnanja, znanja in spretnosti, ki jih mora obvladati posameznik, da lahko ustrezno opravlja določene naloge. (Jelenc, 1991: 70.) Kot bomo pokazali kasneje, je izobraževalna dejavnost, ki jo izvaja Andragoški center Slo- 
venije, čeprav pogosto usmerjena $\mathrm{v}$ pridobivanje praktičnih znanj, podkrepljena z ustreznimi teoretskimi spoznanji in ima skoraj vedno tudi jasno izraženo vrednotno podlago.

Vendar zaradi nekaterih posebnosti izobraževalcev odraslih, ki se vključujejo v naše programe, pojma »usposabljanje« nismo mogli popolnoma ignorirati in ga črtati, in sicer prav iz tistih dveh razlogov, ki ju lahko izluščimo tako iz Muršakove (2002) kot iz Jelenčeve (1991) opredelitve tega pojma. Dejavnost, ki jo izvajamo na Andragoškem centru, ustreza opredelitvi »izpopolnjevanja« kot »poglabljanja in širitve poklicnega znanja«, in sicer tistih izobraževalcev odraslih, ki že delujejo na nekem poklicnem področju, $v$ našem primeru prvenstveno $\mathrm{v}$ izobraževanju odraslih. $\mathrm{V}$ naše programe se namreč večinoma vključujejo osebe, ki že delujejo na nekem poklicnem področju, že imajo takšno ali drugačno temeljno poklicno in strokovno znanje. V vsakem primeru torej svoje temeljno znanje (pa naj bo to andragoško ali drugo) spopolnjujejo. Vendar se ob tem srečujemo še z dvema posebnostima. Prva je ta, da se v naše programe vključujejo tako osebe, ki že imajo temeljno pedagoško-andragoško izobrazbo oz. temeljna znanja s tega področja, hkrati pa tudi osebe, ki tega znanja nimajo. Njih moramo torej najprej usposobiti za opravljanje nalog izobraževalca odraslih, to pa se sklada z Jelenčevo (1991: 70) opredelitvijo tega pojma kot: »postopen razvoj nekega ravnanja, znanja in spretnosti, ki jih mora obvladati posameznik, da lahko ustrezno opravlja določene naloge«. Šele od tod naprej lahko ta oseba svoje andragoško znanje spopolnjuje. Srečujemo pa se še z drugo posebnostjo, v naše programe se namreč vključujejo tudi osebe, ki že imajo temeljno pedagoško-andragoško izobrazbo oz. so po poklicu andragogi; te v programih andragoškega spopolnjevanja to svoje temeljno znanje v vsakem primeru spopolnjujejo. Vendar se takrat, ko se npr. naših programov udeležujejo zato, da bi se usposobile za neko specialistično vlogo izo- braževalca odraslih (npr. mentor PUM, učitelj UŽU, svetovalec v središču ISIO idr.), najprej vključujejo v programe temeljnega andragoškega usposabljanja, saj se morajo za opravljanje te specialistične vloge šele usposobiti, kasneje pa se lahko pridružijo programom andragoškega spopolnjevanja, kjer to znanje spopolnjujejo.

In omenimo še drugi vidik pojma »usposabljanje«, namreč tistega, ki ga Muršak (2002) opisuje kot urjenje ali pridobivanje praktičnih spretnosti, ki »praviloma ni povezano $z$ zahtevnejšimi intelektualnimi operacijami ali strokovno teorijo «. Tudi temu vidiku se $\mathrm{v}$ naših programih ne moremo izogniti. Pomemben del naše dejavnosti andragoškega spopolnjevanja je namreč tudi ciljno praktično usposabljanje za uporabo neke metode, instrumenta, postopka. Vendar to ni vse, ta vidik nadgrajujemo s spodbujanjem razvoja in doseganja zahtevnejših ciljev, ki skupaj vodijo v komeptentnost izobraževalca odraslih. Prav zato v prenovljeni koncept andragoškega spopolnjevanja vpeljujemo kompetenčni pristop, o katerem bomo še spregovorili.

Ob izbiri termina smo se znašli tudi v dilemi, ali za zgoraj opisane namene uporabiti besedo »izpopolnjevanje« ali besedo »spopolnjevanje«. Besedi sta sinonima. Ob pregledu različnih terminologij s področja izobraževanja, ki jih imamo $\mathrm{v}$ slovenskem prostoru, med izrazoma nismo zasledili vsebinske razlike. Tako Terminologija izobraževanja odraslih (Jelenc, 1991) kot Pojmovni slovar za področje poklicnega in strokovnega izobraževanja (Muršak, 2002) sicer izhajata iz opisa pojma »izpopolnjevanje«, vendar ob tem pojem »spopolnjevanje« navajata kot sinonim. Muršak (2002) v komentarju k obrazložitvi pojma »izpopolnjevanje« še zapiše, da zakonodaja daje prednost izrazu izpopolnjevanje, da pa se v strokovni literaturi vedno bolj uporablja izraz spopolnjevanje.

Ko se na Andragoškem centru Slovenije znajdemo v taki terminološki zagati, se ponavadi obrnemo po nasvet $\mathrm{k}$ strokovnjakom za slo- 
venski jezik, jezikoslovcem, lektorjem. Ti so nam v tem primeru pojasnili, da je ena od zakonitosti razvoja jezika tudi njegova racionalnost, tako se predpone vz-, iz- ipd. navadno z leti obrusijo, spremenijo v laže izgovorljiv glas, ki se zapiše $\mathrm{z}$ eno črko. S tega stališča je izraz spopolnjevanje lep in znamenje sodobnega jezika. Ob tem pa so nas opozorili, da v rabi še vedno prevladuje izraz izpopolnjevanje. To upoštevata tudi Slovenski pravopis in Slovar slovenskega knjižnega jezika, ki pri besedi spopolnjevanje uporabnika usmerjata na besedo izpopolnjevanje. Zato lahko vpeljava pojma spopolnjevanje $\mathrm{v}$ praksi povzroči težave in pojmovno zmedo. Po premisleku smo se vendar odločili, da bomo uporabili izraz spopolnjevanje. Ob tem se zavedamo, da lahko vpeljava novega pojma v nekem obdobju povzroči pojmovno zmedo, vendar smo prepričani, da je ena od nalog andragoške stroke tudi ta, da pri razvoju strokovne terminologije sledi razvoju slovenskega jezika oz. ta razvoj tudi pomaga uveljavljati.

$\mathrm{Z}$ vidika opredelitve andragoškega spopolnjevanja, kot ga razvijamo in izvajamo na Andragoškem centru, pa lahko povzamemo, da gre za spopolnjevanje, ki ustreza opredelitvi, ki jo ob pojmu »izpopolnjevanje« navaja Terminologija o izobraževanju odraslih, namreč, da je to spopolnjevanje »namenjeno strokovnjakom $v$ praksi, ki opravljajo zelo zahtevna poklicna dela, da bi lahko sledili razvoju na svojem področju, si pridobivali nove spretnosti, ki jih zahteva delovno mesto, in razumeli družbene okoliščine, $v$ katerih delujejo" (Jelenc, 1991: 63).

Zato smo tudi v logotipu, ki simbolično predstavlja to dejavnost, uporabili termin »andragoško spopolnjevanje«, kar prvenstveno sporoča, da se v to dejavnost vključujejo osebe, ki že delujejo na nekem poklicnem področju, že imajo temeljna znanja z različnih poklicnih področij, čeprav ne nujno s področja izobraževanja odraslih, in se v programe spopolnjevanja vključujejo »iz dela«. Vsebinsko pa dejavnost zajema tako temeljno usposabljanje kot spopolnjevanje za opravljanje različnih vlog izobraževalcev odraslih.

\section{Andragoško spopolnjevanje in strokovni razvoj izobraževalcev odraslih}

Raznovrstnost značilnosti ciljnih skupin, ki jim je namenjeno andragoško spopolnjevanje, nas navaja na potrebo, da temeljni namen te dejavnosti opredelimo dovolj široko, da bomo z njim zajeli potrebe vseh teh skupin, da pa moramo cilje in vsebinsko zasnovo andragoškega spopolnjevanja diferencirati.

Temeljni namen dejavnosti andragoškega spopolnjevanja, ki

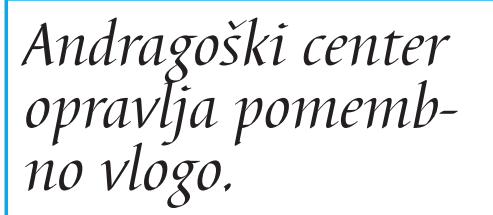
jo razvijamo in izvajamo na Andragoškem centru Slovenije, vidimo v:

- podpori strokovnemu razvoju izobraževalcev odraslih $\mathrm{v}$ tistem delu njihovega strokovnega razvoja, ki poteka $\mathrm{v}$ času, ko na različne načine že delujejo na področju izobraževanja odraslih ali pa že delujejo na drugih področjih in se pripravljajo za vstop na področje izobraževanja odraslih.

Vključevanje $\mathrm{v}$ andragoška usposabljanja in spopolnjevanja lahko izobraževalcem odraslih pri njihovem strokovnem razvoju pomaga $s$ tem, ko si v programih:

- pridobivajo novo znanje, veščine in spretnosti, razvijajo zmožnosti za kompetentno opravljanje svojega dela,

- izmenjujejo svoje dosedanje izkušnje z drugimi ter strokovno vodeno reflektirajo lastne prakse z namenom, da bi jih spopolnili,

- ustvarjajo in razvijajo strokovne povezave $\mathrm{z}$ drugimi izobraževalci odraslih ter $\mathrm{v}$ odnosu z drugimi reflektirajo in razvijajo lastno strokovno identiteto izobraževalca odraslih.

Temeljni cilji, iz katerih izhajajo tudi različne vrste andragoškega usposabljanja in spopolnjevanja, pa se zrcalijo v razvoju in izvedbi programov neformalnega izobraževanja, to pa so: 
- temeljno splošno andragoško usposabljanje: namenjeno je osebam, ki že delujejo v izobraževanju odraslih ali šele vstopajo na to področje, vendar si v svojem dodiplomskem ali podiplomskem izobraževanju niso pridobile pedagoško-andragoških znanj ali pa prihajajo $\mathrm{z}$ drugih poklicnih področij. V programih temeljnega (neformalnega) andragoškega usposabljanja si udeleženci pridobijo temeljna andragoška znanja, ki jih vključuje andragoški ciklus;

- temeljno specialistično andragoško usposabljanje: v ta sklop sodijo usposabljanja, namenjena pripravam za opravljanje specifičnih vlog izobraževalcev odraslih. Največkrat gre za programe $\mathrm{v}$ podporo razvojnim projektom, ki jih snujemo na Andragoškem centru. V te programe se povečini (ne pa v vseh primerih) vključujejo izobraževalci odraslih, ki že imajo formalno pedagoško-andragoško izobrazbo. Pri njih ne gre za pridobivanje temeljnih splošnih andragoških znanj, temveč za temeljna andagoška znanja, ki so povezana s specifičnimi vlogami, kot so vloga svetovalca $\mathrm{V}$ svetovalnih središčih ISIO, mentorja PUM, učitelja UŽU, svetovalca za kakovost idr.

- nadaljnje andragoško spopolnjevanje: ta sklop andragoških spopolnjevanj je namenjen izobraževalcem odraslih, ki že imajo temeljna andragoška znanja, bodisi da so si jih pridobili s formalnimi bodisi $\mathrm{z}$ neformalnimi izobraževalnimi oblikami, oz. že imajo temeljna specialistična znanja za opravljanje specifične vloge izobraževalca odraslih. V teh programih izobraževalci odraslih spopolnjujejo svoja znanja, reflektirajo svojo prakso in jo izmenjujejo $\mathrm{z}$ drugimi ter krepijo lastno strokovno identiteto. Posebno mesto v nadaljnjem neformalnem andragoškem spopolnjevanju ima t. i. andragoško spopolnjevanje $v$ mrežah. Kot smo že omenili, je namreč pomemben del dejavnosti andragoškega spopolnjevanja na Andragoškem centru spopolnjevanje, namenjeno strokovnjakom, ki delujejo v nekem omrežju (npr. omrežje svetovalnih središč ISIO, omrežje svetovalcev za kakovost, omrežje izvajalcev programa PUM). Krepitev vloge andragoškega spopolnjevanja $\mathrm{v}$ teh omrežjih je pomembna za doseganje strokovnega standarda kakovosti. To andragoško spopolnjevanje pa opravlja tudi pomembno funkcijo povezovanja strokovnjakov, ki delujejo $\mathrm{v}$ teh omrežjih, in ustvarja prostor za izmenjavo dobre prakse ter krepitev strokovne identitete izobraževalcev odraslih oz. specialnih vlog izobraževalcev odraslih, kot so npr. svetovalci, mentorji idr.

\section{Kompetenčna zasnova andragoškega spopolnjevanja}

Na tej točki si lahko zastavimo vprašanje, kako razumevanje strokovnega razvoja, ki vključuje tako pridobivanje novih znanj kot reflektiranje obstoječih praks in ravnanj ter oblikovanje strokovne identitete, prenesti $\mathrm{v}$ načrtovanje in izvedbo programov andragoškega usosabljanja in spopolnjevanja. Vse tri vidike smo imeli $\mathrm{v}$ mislih ob snovanju kompetenčnega pristopa pri načrtovanju in izpeljavi andragoškega spopolnjevanja, ki ga vpeljujemo kot konstitutivni element celovitega koncepta andragoškega spopolnjevanja. Pri snovanju metodologij za pripravo programov andragoškega spopolnjevanja je namreč pomemben premislek o vrstah znanja, ki naj jih udeleženci pridobijo $\mathrm{v}$ teh programih, in o spretnostih, veščinah, sposobnostih, ki naj jih razvijejo. Ni namen tega prispevka, da bi podrobneje razlagali posamezne sestavine tega pristopa, za namen naše razprave povejmo le, da smo ga zasnovali na treh elementih, in sicer: opredelitvi temeljnih andragoških procesov, ki imajo svojo konceptualno zasnovo $\mathrm{v}$ andragoškem ciklu, kompetenčnem pristopu in andragoških poklicih oz. andragoških delovnih mestih. Vse to troje smo poskušali povezati, ko smo zasnovali metodologijo našega pristopa in 
na tej podlagi poskušali identificirati zmožnosti, ki jih izobraževalec odraslih potrebuje oz. mora razvijati pri svojem delu (Klemenčič idr., 2009). Za začetek smo takšen pristop zastavili pri vlogi ali delovnem mestu vodje in organizatorja izobraževanja odraslih.

Pri tem delu smo se precej časa ustavili ob konceptu kompetenc/zmožnosti ter veliko razmišljali o prednostih in pasteh, ki jih prinaša. Analizirali smo opozorila številnih avtorjev, ki opozarjajo na nevarnost prevelikega drobljenja kompetenc, kar pravzaprav vodi $\mathrm{v}$ redukcijo poklica (ali pa je njena posledica) na »statistično-analitične enote, $v$ katere se razvršča delo, sorodno po vsebini in zahtevnosti« (Muršak, 2002: 80). Na to past je zelo ilustrativno pokazal neki učitelj, ko je v razpravi o danes zelo priljubljenih kompetenčnih pristopih opozoril na nevarnost, da bi »namesto kompetentnih učiteljev dobili učitelje s tisočerimi kompetencami« (Bates, 1997).

Precej skeptično in previdno smo se tako odločili za uporabo kompetenčnega pristopa. Naše dvome smo nekoliko ublažili, ko smo med različnimi pojmovanji zmožnosti kot izhodišče za načrtovanje programov andragoškega spopolnjevanja uporabili tisto, po katerem zmožnosti razumemo kot preplet različnih sestavin, to pa so:

- kognitivna oz. spoznavna zmožnost: obvladovanje principov, teorij, konceptov, tudi razvoj višjih spoznavnih ravni - sistematično povezano znanje, obvladovanje raznih miselnih operacij, razvoj kritičnega, ustvarjalnega mišljenja itd.;

- funkcionalna oz. akcijska zmožnost: zmožnost in pripravljenost angažirati se, nekaj narediti, znanje smiselno in koristno uporabiti $\mathrm{v}$ življenju in delu; spretnosti, sposobnosti in veščine, potrebne za reševanje problemov v vsakodnevnih situacijah oz. za opravljanje konkretnih dejavnosti, in

- osebnostne ali socialne zmožnosti: vključujejo tudi čustveno/motivacijsko dimenzijo; obvladovanje družbenega prostora, vsto- panje v razmerja, kar vključuje tudi etično dimenzijo, osebne in družbene vrednote, odnos do lastne strokovne vloge in osebnostne rasti (prirejeno po: Medveš, 2006; Marentič Požarnik, 2006).

$\mathrm{S}$ takih prepletom različnih vrst znanj namreč lahko zaobjamemo prav vse tri vidike strokovnega razvoja izobraževalca odraslih, kot smo jih opredelili zgoraj.

$\mathrm{Na}$ potrebo po tovrstnem prepletu različnih zmožnosti in njihovem povezovanju pri razvoju kompetentnosti izobraževalca pokaže tudi Korthagen (2004) v svoji razpravi z naslovom »V iskanju bistva dobrega učitelja«, v kateri razvije model jedrne refleksije. Posebej opozori, da je treba pri izobraževanju in stalnem strokovnem spopolnjevanju učiteljev preseči raven, ki seže zgolj do pridobivanja veščin, spretnosti, metod in tehnik. Zato v svoj model umesti kompetence, ki jih razume kot širše zmožnosti. A hkrati meni, da je treba pri izobraževanju učiteljev upoštevati tudi ravni, na katerih se oblikujejo učiteljeva prepričanja, njegova strokovna identiteta in najbolj esencialno dojemanje lastne vloge, ki se kaže v temeljnih vrednostnih predpostavkah lastnega poslanstva oz. dojemanja sebe kot avtentične osebnosti. V metodologiji za načrtovanje programov andragoškega usposabljanja in spopolnjevanja smo poskušali zaobjeti tudi tovrstne kompetence/zmožnosti. Programi usposabljanja in spopolnjevanja, ki jih razvijamo na Andragoškem centru, zajemajo tako trening veščin in spretnosti kot tudi razvoj kompleksnejših zmožnosti, med katere poleg pridobivanja kompleksnejšega konceptualnega znanja sodi tudi razvoj zmožnosti samorefleksije lastne prakse, samospraševanja o lastni strokovni identiteti, premislek in opredelitev smisla/poslanstva in ciljev svojega strokovnega delovanja.

Pri načrtovanju programov andragoškega usposabljanja in spopolnjevanja je upoštevanje omenjenih izhodišč pomembno iz dveh razlogov:

- Že pri opredeljevanju zmožnosti v programih je treba temeljito premisliti o različnih 
Slika 1: Model jedrne refleksije

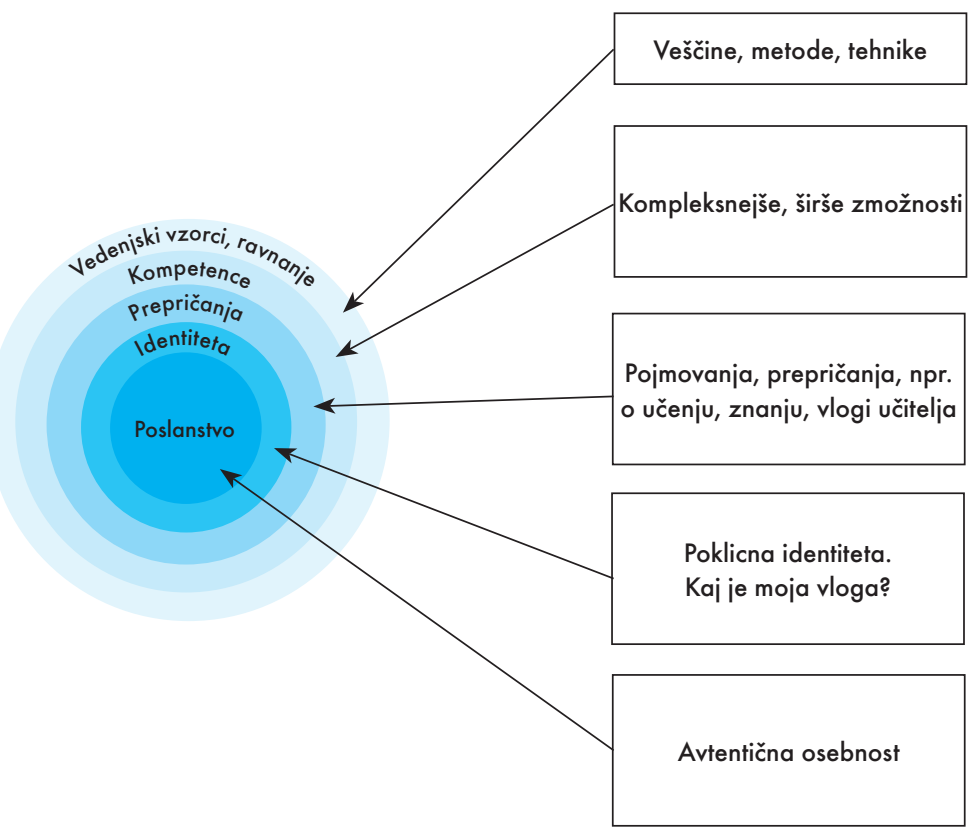

ravneh zmožnosti, še bolj pa o tem, kako jih bomo dosegali, saj se vseh ne da oblikovati in razvijati $\mathrm{z}$ enakimi metodami.

- Ni nujno, da v vseh programih razvijamo zmožnosti na vseh ravneh. Nekateri programi so namenjeni pridobivanju veščin, spretnosti, temu, da se izobraževalec odraslih nauči uporabljati neko metodo, sodobni učni pripomoček. Ti programi so ponavadi krajši in zelo ciljno in praktično usmerjeni. Na enodnevnih ali dvodnevnih usposabljanjih je namreč težko odpirati vprašanja strokovne identitete ter o njih poglobljeno razmišljati. Kadar se želimo ukvarjati s takimi vprašanji, je treba to upoštevati pri načrtovanju spopolnjevanj in hkrati vedeti, da obravnava teh tematik največkrat zahteva več časa in ustrezne pristope. Ob tem moramo še razumeti, da razvoja strokovne identitete pri andragoškem spopolnjevanju ni mogoče opredeljevati kot končnega cilja v smislu standardov znanja, temveč ga je treba v kurikul umestiti kot procesni cilj, ki ga razvijamo v dejavnosti.

\section{Andragoški ciklus kot izhodišče za načrtovanje programov andragoškega spopolnjevanja}

Kot pomemben vidik strokovnega razvoja izobraževalca odraslih smo opredelili, da si mora stalno pridobivati novo znanje ter obstoječe znanje reflektirati, preoblikovati in spopolnjevati. Ključno vprašanje, ki si ga ob tem zastavlja načrtovalec programov andragoškega spopolnjevanja, pa je, katero je to znanje. Vpogled v raznolikost ciljnih skupin in raznolikost družbenih potreb, na katere naj bi odgovarjali tudi izobraževalci odraslih, hitro pokaže, da odgovor na to vprašanje ni enostaven. Danes je raziskovanje potreb izobraževalcev odraslih po znanjih še toliko bolj zapleteno, ker je družba, v kateri živimo, postala veliko bolj dinamična, kot je bila $\mathrm{v}$ preteklosti. Težava ni toliko v identificiranju potreb po znanjih, ki jih izobraževalci odraslih kažejo danes, večji izziv je danes vedeti, katero je tisto znanje, ki ga bodo potrebovali $\mathrm{v}$ prihodnosti. Če smo razvojno naravnani, pa vemo, da misliti zgolj za danes ni dovolj. V koncept nadaljnjega razvoja andragoškega spopolnjevanja, ki ga izvajamo na Andragoškem centru, je zato treba vključiti elemente, ki bodo na eni strani vsebinsko zamejili prostor, v katerega vstopamo $\mathrm{z}$ andragoškim spopolnjevanjem, hkrati pa omogočali dinamično in fleksibilno delo znotraj tega prostora.

In še nekaj je pomembno. Če govorimo o andragoškem spopolnjevanju kot delu celovitega sistema izobraževanja izobraževalcev odraslih v Sloveniji, potem moramo najti vsebinsko stično točko med začetnim formalnim andragoškim izobraževanjem in neformalnim andragoškim spopolnjevanjem. Analize potreb izobraževalcev odraslih, ki smo jih v zadnjih letih opravili na Andragoškem centru (Birman Forjanič idr., 2008; Klemenčič idr., 2009; Žalec in Đorđevič, 2009), so nas prepričale, da lahko za te namene tudi danes uporabimo koncept, ki je andragogiki najbolj imanenten, to je koncept andragoškega cikla. Menimo, da je tako, kot je bilo to značilno 
za pretekla obdobja, tudi danes koncept andragoškega cikla tisto vsebinsko ogrodje, konceptualna stična točka med različnimi vrstami izobraževanja izobraževalcev odraslih, ki zadosti vsem zgoraj navedenim merilom dinamičnosti. Zato smo ob snovanju koncepta nadaljnjega razvoja andragoškega spopolnjevanja prav andragoški cikel vzeli kot vsebinsko izhodišče za oblikovanje kompetenčnega okvira. Z njegovo pomočjo smo opredelili temeljne andragoške procese, ki potekajo v različnih delovnih situacijah, v katerih delujejo andragoški delavci. Ti temeljni andragoški procesi so namreč izhodišče za premislek o kompetencah/zmožnostih, ki jih izobraževalci odraslih potrebujejo, da bodo te procese strokovno opravili. To smo v prvi fazi opravili na primeru delovnega mesta organizatorja/vodje izobraževanja odraslih.

Takšen konceptualni okvir smo v nadaljevanju najprej uporabili kot izhodišče za ovrednotenje dosedanje ponudbe programov andragoškega spopolnjevanja. Še pomembneje pa je, da nam tako zastavljen koncept, utemeljen na raznovrstnih vlogah izobraževalcev odraslih, kompetenčnem pristopu in andragoškem ciklu, daje trdno, hkrati pa tudi fleksibilno in dinamično izhodišče za načrtovanje nove programske ponudbe andragoškega spopolnjevanja $\mathrm{v}$ prihodnosti.

\section{Priznavanje poprejšnjega znanja kot konstitutivni element koncepta strokovnega spopolnjevanja}

V koncept nadaljnjega razvoja andragoškega spopolnjevanja smo kot pomemben element uvrstili tudi možnost priznavanja poprej pridobljenega znanja, ki ga izobraževalci odraslih že imajo. Pri tem smo v konceptu opredelili dva pomembna vidika priznavanja, od katerih je prvi umeščen $\mathrm{v}$ andragoško spopolnjevanje, ki ga izvajamo na Andragoškem centru, drugi pa presega to spopolnjevanje in pomeni ustvarjanje nekakšnega »mostu« do sistema formalnega izobraževanja izobraževalcev odraslih. Gre za to, da bi imeli izobraževalci odraslih možnost:
- da ob vstopu v programe usposabljanja in spopolnjevanja, ki jih izvajamo na Andragoškem centru, uveljavijo znanje, ki ga že imajo in so si ga pridobili v različnih drugih izobraževalnih oblikah oz. z delom,

- da ob vstopu v formalne programe za pridobivanje pedagoško-andragoške izobrazbe, ki jih izvajajo različne fakultete, uveljavljajo znanje, ki so si ga pridobili v neformalnem andragoškem spopolnjevanju, ki ga izvajamo na Andragoškem centru.

Na Andragoškem centru smo v letu 2011 odprli prostor za udejanjanje prvega opisanega elementa priznavanja prejšnjega znanja. Svet Andragoškega centra je sprejel Pravilnik o priznavanju že pridobljenega znanja $\mathrm{v}$ programih spopolnjevanja na Andragoškem centru Slovenije, ki vsem, ki se nameravajo udeležiti katerega izmed programov usposabljanja ali spopolnjevanja, ki trajajo več kot 24 ur, omogoča, da zaprosijo za priznavanje svojega že pridobljenega znanja. Opredeljen je postopek priznavanja, ki ga vodi komisija Andragoškega centra za priznavanje že pridobljenega znanja, ki jo imenuje direktor centra. Kandidatu se prizna že pridobljeno znanje ne glede na to, kje in kako si ga je pridobil, če izkaže, da njegovo znanje po vsebini in zahtevnosti v celoti ali v posameznem delu ustreza ciljem, vsebinam in zahtevnosti programov usposabljanja in spopolnjevanja, ki jih izvaja Andragoški center. $\mathrm{S}$ tem je bil narejen pomemben razvojni korak, ki smo ga podkrepili s tem, da smo poenotili metodologijo priprave programov andragoškega spopolnjevanja ter ustvarili spletno programoteko programov andragoškega spopolnjevanja (http://izobrazevanje.acs.si/programoteka/), v kateri bomo postopoma objavili vse programe andragoškega spopolnjevanja, razvite na centru. To bo izobraževalcem odraslih olajšalo vpogled v temeljne cilje, kompetence/zmožnosti in vsebine, ki jih zajemajo programi, v katere se vključujejo, ter njihovo primerjavo z znanji, ki jih že imajo in za katere želijo, da bi se jim 
ob vstopu v naše programe andragoškega spopolnjevanja priznala.

Za udejanjanje drugega vidika priznavanja, namreč odpiranje poti za to, da bi izobraževalci odraslih, ki so si znanje pridobivali v programih andragoškega usposabljanja in spopolnjevanja na Andragoškem centru, kasneje pa se vključijo tudi $\mathrm{v}$ javnoveljavni program za pridobitev pedagoško-andragoške izobrazbe, imeli možnost, da se jim določeno znanje prizna, pa je v prihodnje treba pritegniti $\mathrm{k}$ sodelovanju nosilce tega formalnega izobraževanja. Zato bo Andragoški center dal pobudo in povabil te
"Uvajanje študija andragogike na Univerzi v Ljubljani je zgodba uspeha ...« nosilce $\mathrm{k}$ skupnemu premisleku o možnostih za odpiranje te poti priznavanja poprejšnjega znanja. Odpiranje teh poti ter povezovanje formalnega izobraževanja in neformalnega spopolnjevanja, naj gre za priznavanje znanja, pridobljenega $\mathrm{z}$ neformalnim usposabljanjem in spopolnjevanjem, kot za druge oblike sodelovanja, se nam zdi pomembno za razvoj celovitega in koherentnega sistema izobraževanja izobraževalcev odraslih. In morda je bilo tega sodelovanja $\mathrm{v}$ preteklosti premalo!

\section{Raziskovalno in razvojno delo, razvoj nosilnih kadrov andragoškega spopolnjevanja ter sodelovanje z zunanjimi strokovnjaki}

Ob koncu predstavitve izhodišč nadaljnjega razvoja dejavnosti andragoškega spopolnjevanja pa se ustavimo še pri tistem, kar je za razvoj te dejavnosti najpomembneje. Vrnimo se še enkrat k Sabini Jelenc Kraševec (2011) in njeni kritični analizi sedanjega stanja na področju izobraževanja odraslih. Ob koncu te analize zapiše: »Čas je, da se zaposleni na področju izobraževanja odraslih in andragoška stroka ustrezno zavzamejo in organizirajo, da pospešijo ugodnejši razvoj že uveljavljenih praks ter znova spodbudijo razcvet področja izobraže- vanja odraslih, ki prej ali slej vpliva tudi na družbeno blaginjo." (Jelenc Krašovec, 2011: 9.) Gre za poziv, ki mora najti pot do vsakega izobraževalca odraslih in do vseh institucionalnih nosilcev izobraževanja odraslih in v njem/ njih spodbuditi premislek o njegovem/njihovem lastnem prispevku k nadaljnjemu razvoju in revitalizaciji izobraževanja odraslih.

Kar zadeva udejanjanje nadaljnjega razvoja andragoškega spopolnjevanja na Andragoškem centru, s katerim želimo prispevati $\mathrm{k}$ strokovnemu razvoju izobraževalcev odraslih ter posledično h kakovostnemu delu na tem področju, se pridružujem vsem tistim andragogom, ki opozarjajo, da takšen nadaljnji razvoj ne bo mogoč brez:

- okrepitve raziskovalnega dela, ki poleg raziskovanja potreb po znanjih vključuje tudi proučevanje značilnosti izobraževalcev odraslih, poti, po katerih prihajajo $\mathrm{v}$ izobraževanje odraslih, vplivov, ki jih ima na vlogo izobraževalcev odraslih njihov zaposlitveni status idr.;

- nadaljnjih vlaganj v razvojno delo, ki mora preliti ugotovitve raziskovalnega dela $\mathrm{v}$ razvojno aplikativne rešitve. Ni vloga Andragoškega centra, da reproducira programe andragoškega usposabljanja in spopolnjevanja, ki jih (lahko) izvajajo drugi izvajalci. Andragoški center mora prvenstveno ponuditi izvirne programe, ki izhajajo iz ugotovljenih oz. anticipiranih potreb, za katere še ni ustrezne programske ponudbe. Ob tem se morajo strokovnjaki, ki razvijajo to dejavnost, znati upreti pritiskom izobraževalnega trga in pogosto glasnim zahtevam uporabnikov, financerjev in drugih interesnih skupin po poenostavitvi vsebin usposabljanj in spopolnjevanj, hitrejših poteh do njihovega zaključka ter njihovega prevelikega krčenja v primerih, ko to pomeni zniževanje standardov kakovosti. Nosilci dejavnosti andragoškega spopolnjevanja na Andragoškem centru moramo biti zavezani temeljnim načelom in ciljem 
andragoške vede, naša odgovornost je tudi, da to vedo udejanjamo. To pa ne gre vedno po najlažji poti in zahteva:

- vlaganja v razvoj strokovnjakov, ki so (notranji) nosilci dejavnosti andragoškega spopolnjevanja: prav v tej točki je Andragoški center $\mathrm{v}$ zadnjih letih doživel številne pretrese, ki so močno posegli v kadrovsko strukturo in spodjedli zdravo kadrovsko jedro, ki je poglavitno gonilo delovanja vsake institucije. Škode, ki je bila s tem narejena, ni mogoče popraviti čez noč. Razmere se lahko v tem pogledu sanirajo le ob večletnem načrtnem in sistematičnem vlaganju v razvoj kadrov, ki je vsebinsko premišljeno in finančno podprto;

- krepitev sodelovanja z zunanjimi strokovnjaki (teoretiki in praktiki), ki se vključujejo tako v izvajanje andragoških spopolnjevanj kot $\mathrm{v}$ raziskovalno in razvojno delo. Nemogoče bi bilo pričakovati, da lahko sodelavci Andragoškega centra pokrijejo prav vse potrebe po andragoškem usposabljanju in spopolnjevanju. Zato niti številčno ni dovoljšnje ekipe niti ne bi bilo mogoče zagotoviti vsebinske pokritosti za številne tematike, ki jih zajemajo raznovrstni programi in so pogosto zelo specialistično naravnane. Zato je sodelovanje $\mathrm{z}$ zunanjimi strokovnjaki ter krepitev povezovanja z njimi izrednega pomena za uspešnost našega dela.

Za konec tega premisleka se vrnimo na začetek. Ni smiselno tajiti, da danes živimo $v$ težavnih časih. Naša družba je na pomembnih razpotjih, ki niso zgolj ekonomske, temveč tudi vrednotne narave. Tudi si ni smiselno zatiskati oči pred tem, da se danes področje izobraževanja odraslih ubada s številnimi težavami in ovirami. Veliko je odvisno od širšega družbenega konteksta in politične podpore, vendar ne verjamem, da so izobraževalci odraslih, ki so na to področje vstopali pred nami in dosegli veliko, vedno delali v ugodnih političnih, gospodarskih in drugih razmerah. $\mathrm{O}$ tem me prepriča tudi misel, ki jo je dr. Ana Krajnc zapisala v zaključku svojega prispevka Študij andragogike in izobraževanje andragogov.

Takole pravi: »Uvajanje študija andragogike na Univerzi $v$ Ljubljani je zgodba uspeha in resničnih dosežkov. Ne bi bilo povsem naravno, če ne bi $v$ zakulisju delovale tudi razvoju nasprotne sile. Probleme imamo vsi ljudje, razlikujemo se le po tem, ali se osredotočimo na zmage ali izgube. Zmagovalci se osredotočijo na zmage, dosežke. Zgubarji se največ ukvarjajo z ovirami in izgubami, zato se vedno bolj oddaljujejo od ciljev, namesto da bi se jim vztrajno približevali kot zmagovalci. Nasprotovanja in ovir na poti do cilja, da razvijemo študij andragogike, smo pretežno puščali ob strani. Bolj smo se zanašali na podporo in sodelovanje. Naj dejstva govorijo o tem, koliko smo napravili in kako daleč nam je uspelo priti.« (Krajnc, 2011: 25.)

$\mathrm{Na}$ vseh nas, ki danes delujemo v izobraževanju odraslih, tako tistih, ki imajo v rokah škarje in platno izobraževalne politike, kot tistih, ki razvijamo stroko, je odgovornost, da preteklih dosežkov ne izničimo, temveč jih ohranimo in okrepimo. Ni druge poti, če želimo še naprej razvijati in udejanjati andragogiko kot vedo o izobraževanju odraslih. V nasprotnem primeru moramo namreč sprejeti to, da bomo kmalu spet postali le še »pridruženi člani« kakšne druge vede, kakšne druge institucije, kakšnega drugega časa ... Menim, da lahko, če se hočemo izogniti udejanjenju takšnega vsem nam neljubega scenarija, iz dosedanjih dosežkov črpamo spodbudo in samozavest, ki ju potrebujemo za nadaljnji razvoj področja, ki naj se razvija tako, da bo pripomoglo $\mathrm{k}$ večji družbeni blaginji za vse. 


\section{LITERATURA}

ALPINE - Adult Learning Professions in Europe (2008). Leiden: Plato. Dostopno na:http:// ec.europa.eu/education/more-information/doc/ adultprofreport_en.pdf (21. 11. 2011)

Bates, I. M. (2002): The competence and outcomes movement: the landscape of research, 1986-1996. Leeds: School of education University of Leeds. Dostopno na:http://www.leeds.ac.uk/educol/documents/00002216.htm (21. 11. 2011)

Bron, A.; Jarvis, P. (2008). »Identities of Adult Educators: Change in Professionality«. V: Nuissl E. in Lattke S.(ur.), Qualifying adult learning professionals in Europe. Bielefeld.

Birman Forjanič, Z.; Đorđević, N.; Klemenčič, S.; Vilič Klenovšek, T.; Možina, T., Orešnik Cunja, J.; Žalec, N. (2008). Prikaz dosežkov in razvojnih izzivov izobraževalne dejavnosti Andragoškega centra Slovenije - Izhodišča za oblikovanje nove zasnove andragoškega spopolnjevanja. Ljubljana: Andragoški center Slovenije.

Ermenc, K. (2006). »Kompetenčni pristop h kurikularnemu načrtovanju: pojem, nekatere implikacije in dileme«. Vzgoja in izobraževanje, 37, 1: 21-26.

Jelenc, Z. (ur.) (1991). Terminologija izobraževanja odraslih. Ljubljana: Pedagoški inštitut pri Univerzi v Ljubljani.

Jelenc, Z. (2010). »Usposabljanje in identiteta izobraževalcev odraslih«. Andragoška spoznanja, 16, 3: 34-41.

Jelenc Krašovec, S. (2011). »Paleta izbire na področju izobraževanja odraslih - resničnost in obeti«. Andragoška spoznanja, 17, 2: 2011.

Karm, M. (2007). Professional development opportunities of Estonian Adult Educators. Tallin: Tallin University.

Klemenčič, S.; Možina, T.; Žalec, N. (2009). Kompetenčni pristop k spopolnjevanju andragoških delavcev. Ljubljana: Andragoški center Slovenije.

Krajnc, A. (2011). »Študij andragogike in izobraževanje andragogov«. Andragoška spoznanja, 17, 2: $12-27$.

Korthagen, F. A. J. (2004). »In search of the essence of a good teacher: Towards a more holistic approach in teacher education «. Teaching and Teacher Education, 20: 77-97.
Marentič Požarnik, B. (2006). »Uveljavljanje kompetenčnega pristopa terja vizijo, pa tudi strokovno utemeljeno strategijo spreminjanja pouka«. Vzgoja in izobraževanje, 37, 1: 27-33.

Mcintosh, S. (2008). Professionalization of adult educators in a Canadian Learning Society. Canada: Athabasca University.

Medveš, Z. (2006): »Informativni in formativni nivo v kurikularnem načrtovanju.«Vzgoja in izobraževanje, 37, 1: 29-31.

Mezirow J. (2000). »Learning to Think Like and Adult. Core Concepts of Transformation Theory." V: J. Mezirow (eds). Learning as transformation: critical perspectives on a theory in progress. San Francisco: Jossey Bass.

Milana, M.; Larson, A. (2010). Becoming Adult Educators in the European Area, National report. Copenhagen: Danish School of Education, Aarhus University. Dostopno na:

http://pure.au.dk/portal/files/664/BAEA_national_report_Denmark.pdf (21. 11. 2011)

Možina, T.; Birman Forjanič, Z. (2009). Razvoj novih pristopov pri spopolnjevanju andragoških delavcev - prikaz, izsledkov vodenih intervjujev. Ljubljana: Andragoški center Slovenije.

Muršak, J. (2002): Pojmovni slovar za področje poklicnega in strokovnega izobraževanja. Ljubljana: Ministrstvo za šolstvo, znanost in šport, Urad RS za šolstvo, Center RS za poklicno izobraževanje.

Muršak, J.; Javrh, P.; Kalin, J. (2011). Poklicni razvoj učiteljev. Ljubljana: Znanstvena založba Filozofske fakultete Univerze v Ljubljani.

Slovar slovenskega knjižnega jezika (2008): Ljubljana: ZRC SAZU. Dostopno na: http://bos.zrc-sazu. si/sskj.html (21. 11. 2011)

Skupna evropska načela za kompetence in kvalifikacije učiteljev (2007). Bruselj: Evropska komisija.

Tobias, R. M. (1996) »The professionalisation of adult education in Aotearoa New Zealand, 1930s-1960s«. Critical Perspectives on Cultural and Policy Studies in Education, 15, 2: 94-108.

Žalec, N.; Đorđević, N. (2009). Razvoj novih pristopov pri spopolnjevanju andragoških delavcev - Prikaz izsledkov fokusnih skupin. Ljubljana: Andragoški center Slovenije. 
1 Muršakov (2002) Pojmovni slovar za področje poklicnega in strokovnega izobraževanja opredeljuje poklic kot: »Tip dela, ki ga opravlja posameznik, pogosto opisan v obliki širokega kroga spretnosti in kompetenc, ki so zanj potrebne."Pozornost pa velja nameniti tudi dvema dimenzijama razumevanja poklica, na kateri avtor terminološkega slovarja opozarja v komentarju $k$ tej opredelitvi. Sodobne opredelitve poklica, tako tudi standardna klasifikacija poklicev, ki jo poznamo v Sloveniji, namreč poklic razumejo kot niz del, katerih poglavitne naloge in dolžnosti so si zelo podobne, ali kot statistično-analitično kategorijo, v katero se razvršča delo, sorodno po vsebini in zahtevnosti, ki ga je opravljala, ga opravlja ali bi ga lahko opravljala praviloma ena oseba.

Kot opozarja Muršak, ima poklic v slovenščini tradicionalno širši pomen od zgolj tega, ki se opredeli kot »statistično-analitična kategorija, $v$ katero se razvršča delo, sorodno po vsebini in zahtevnosti«. Gre za dilemo, ki se v našem prostoru kaže kot prehod od širokega pojmovanja poklica kot poklicanosti v smislu protestantske tradicije, ki razume poklic kot življenjsko poslanstvo z vsemi pripadajočimi značilnostmi, do pojmovanja poklica kot zaposlitve (angl. »occupation«), ki označuje le še delo, ki ga posameznik opravlja, ne pa tudi njegovo pripadnost in zavezanost poklicni etiki. Poleg opisanega pomeni tudi poklic v pomenu profesije (torej akademski poklic kot naziv diplome, npr. zdravnik, pravnik) (Muršak, 2002).

2 Standardna klasifikacija poklicev v Sloveniji opredeljuje za področje izobraževanja odraslih dva poklica: andragog/andragoginja in organizator/organizatorka izobraževanja. 